преемственности, например, жернов возлагался на могилу последнего представителя рода еще в 20-е годы XX века.

Попытка комплексного анализа культурно-производственного объекта предпринимается нами, и в отношении выбранного объекта исследования на территории Северной Осетии, впервые, и в случае успешности его результатов, выработанные методы и умения будут применены и в отношении других подобных объектов.

$$
* * *
$$

1. Каофенгофер А. Подробное изъяснение о колесах в водяных мельницах и о внутреннем строении пильных мельниц с десятью листами. / Пер. с нем. Курск, 1793. 47 с.

2. Мильчик М.И., Ушаков Ю.С. Деревянная архитектура русского Севера. Страницы истории. М., 1981. $129 \mathrm{c}$.

3. Красноречьев Л.Е., Тынтарева Л.Я. Как красота и мера скажут: Памятники древнего деревянного зодчества Новгородской области. Л.: Лениздат, 1971. 96 с.

4. Афанасьев П. Мукомольные мельницы: устройство мельничных машин и мельниц. Приготовление муки и крупы. СПб., 1883. 267 с.

5. Штурм Л.К. Совершенное описание строения мельниц М.: Сенатская типография, 1782. 162 с.

6. Милютин А. Руководство к построению водяных мельничных колес основанное на законах Гидро Динамики. М., 1828. 103 с.

7. Пчелина Е.Г. Осетинская мельница «къада куырой» // Известия Северо-Осетинского научноисследовательского института. Т. XXV. Орджоникидзе. 1966. С. 254-285.

8. Семенов С.А. Происхождение земледелия. Л.: Наука, 1974. 318 с.

9. Калоев Б.А. Земледелие народов Северного Кавказа. М., 1981. 249 с.

10. К Клапрот Ю. Путешествие по Кавказу и Грузии // ОГРИП. Орджоникидзе, 1967. С.105-180.

11. Магометова А.X. Общественный строй и быт осетин (XVIII-XX вв.) Орджоникидзе, 1974. 369 c.

12. The Athlone history of witchcraft and magic in Europe. Vol. 6. Witchcraft and magic in Europe: The 20th century / Ed. by B. Ankarloo, S. Clark. London, 1999. Pp. 141-235.

13. Ashforth A. Of secrecy and the commonplace: Witchcraft and power in Soweto // Social Research. 1996. Vol. 63. Pp.1183-1234.

14. Сокаева Д.В. Образ женщины-волчицы (ус-бирæгъ) осетинской несказочной прозы в контексте фольклора индоевропейских народов // Известия СОИГСИ. Вып. 1(40). 2007. С. 201-222.

15. Бесолова Е.Б. Язык и обряд: Похоронно-поминальная обрядность осетин в аспекте ее текстуальновербального выражения. Владикавказ, 2008. 406 с.

16. Абаева Ф.О. Обрядовый свадебный текст осетин. Лексика. Семантика. Символика. Владикавказ, 2013. $251 \mathrm{c}$.

17. Дзлиева Д.М. Динамика исторического развития свадебного музыкального фольклора осетин. Владикавказ, 2014. 363 с.

18. Туаллагов А.А. Зеленчукская надпись. Владикавказ, 2015. 430 с.

\title{
Соколова М.Г. \\ Тополь как элемент «троемирия» в русской пейзажной лирике
}

ФГБОУ ВО «Тольяттинский государственный университет» (Россия, Тольятти)

doi: $10.18411 / s p c-26-10-2017-08$

idsp: 000001:spc-26-10-2017-08

\section{Аннотация}

Данная статья посвящена характеристике языкового воплощения образа тополя как элемента пейзажного комплекса в русской лирике. Целью исследования является выявление устойчивых метафорических средств, репрезентирующих образ тополя как элемента идеального поэтического пейзажа. В результате проведенного исследования установлено, что с образом тополя связан ряд устойчивых поэтических формул, которые обладают семантической многоплановостью. В статье описаны символические значения, лежащие в основе метафорического образа поэтического тополя.

Ключевые слова: русская лирика, идеальный пейзаж, поэтический комплекс, образ тополя, поэтическая формула. 
Проблема выявления и описания поэтики пейзажных комплексов в художественном тексте неоднократно становилась предметом рассмотрения в литературоведческих, лингвистических и культурологических работах. К наиболее значимым их них следует отнести исследование М.Н. Эпштейна, к котором представлена система устойчивых традиционных поэтических растительных мотивов, описаны законы их сочетания в пейзажных комплексах [11]. В работе В.Н. Топорова характеризуется поэтический комплекс моря, представленный тремя мотивами, которые основываются на архетипических метафорических образах: «степь - море», «небо - море», «дно моря - образ смерти» [9]. Роль пейзажа в контексте творчества отдельных писателей исследуется в работах Н.Д. Жуковой, С.В. Зеленцовой, О.Ю. Уллис $[2 ; 3 ; 10]$. Ассоциативно-образные модели концептуализации пейзажа и их лингвостилистическая репрезентация в малой прозе И.А. Бунина охарактеризованы в работе О.В. Рудневой [8]. Анализ пейзажа как особого типа текста, имеющего определенную структуру и семантику содержится в исследовании О.А. Витрук [1]. Таким образом, проблема изучения пейзажных описаний разрабатывалась преимущественно в литературоведческих работах. Языковое воплощение образа тополя как элемента пейзажного комплекса в русской лирике еще не становилось предметом специального исследования в научной литературе.

Целью настоящей статьи является выявление устойчивых метафорических средств, репрезентирующих образ тополя как элемента идеального поэтического пейзажа, описание символических значений, лежащих в основе метафорического образа поэтического тополя.

Исследование выполнено на материале поэтического корпуса Национального корпуса русского языка [7]. В результате работы с поэтическим корпусом было отобрано более 600 текстовых фрагментов с лексемой «тополь» из произведений, относящихся к различным хронологическим периодам русской поэзии (В.А. Жуковский, В.В. Капнист, А.Н. Плещеев, И.Н. Голенищев-Кутузов, И.В. Елагин, И.Г. Эренбург, И.В. Чиннов, А.А. Тарковский, С.М. Гандалевский и др.).

Под «троемирием» в данной статье мы понимаем устойчивый поэтический комплекс - «небо - земля - вода», который реализуется преимущественно элементами идеального пейзажа. Идеальный пейзаж как разновидность пейзажа сформировался еще в античной и средневековой европейской литературе и по традиции включает пять устойчивых основных элементов: 1) «мягкий ветерок, овевающий, нежащий, доносящий приятные запахи; 2) вечный источник, прохладный речек, утоляющий жажду; 3) цветы, широким ковром устилающие землю; 4) деревья, раскинувшиеся широким шатром, дающие тень; 5) птицы, поющие на ветвях» [11, с. 131]. Таким образом, ветерок, птицы, на ветвях, небесный свод являются маркером небесной сферы, цветы, деревья маркируют земную сферу, источник маркирует сферу воды.

«Троемирие» является выражением трехмерной пространственной организации поэтического пейзажа. Такой состав элементов и их сочетание призваны реализовать эстетическую категорию прекрасного. Данные элементы связаны с потребностями пяти человеческих органов чувств и полностью гармонируют с природой человека.

Классическая традиция описания идеального места наиболее полно воплощается в русской поэзии XVIII- начала XIX веков, тем не менее идиллические элементы пейзажа получают воплощение в творчестве поэтов всех последующих хронологических периодов русской литературы. Как показало проведенное исследование, именно тополь чаще всего взаимодействует со сферой воды и неба, осуществляет их взаимосвязь пейзажной лирике. Подтверждением сказанному служит, большое количество поэтических фрагментов, одинаково построенных по законам трехмерной пространственной организации поэтического пейзажа. Приведем некоторые примеры (цитируются по Национальному корпусу русского языка [7]): Неси ж сюда, где тополь с ивой // Из ветвий соплетают кров, // Где вьется ручеек игривой 
//Среди излучистых брегов, // Вино, и масти ароматны, / И розы, дышащчие миг (В.А. Жуковский. К Делию. 1809); Сребриста тополь, ель высока / Где дружны ветви в свод плетут, / С журчаньем где струи потока, / Извившись, торопко текут (В.В. Капнист. Совет. 1806), И ты будешь как ландшафт спокойный - Вечер, пруд, и тонкий тополь стройный, И бессмертный полог голубой (И.Н. Голенищев-Кутузов «Только нежный, бледно-голубой...». 1933-1938), Тополи над спящими водами, Как призраки, стоят, луной озарены; Усеян свод небес дрожащими звездами, В глубокий сон поля и лес погружень (А.Н. Плещеев. Странник. 1845)

Основными пространственными детерминантами, определяющими место произрастания поэтического тополя, являются лексемы, репрезентирующие сферу воды: над брегом, над водами, над прудом, над речкой, над арыками, в реке толпились, под влажным ветром у забора, под грозой, сходились к реке.

Отметим, что поэтический комплекс «троемирия» может выражаться за рамками идеального пейзажа в самых различных индивидуально-авторских вариантах: зима, снег (вода) - тополь - летчик (небо); снег, сырость, лужи (вода) - тополь - соловей, заря (небо) и др. Приведем соответствующие контексты: Снег валит, тяжелеет голова, / Хоть сырость разводи. Но эти слезы / Иных времен, где в занавеси дрожь, / Бьет соловей, заря пльвет по лужам, / Будильник изнемог, и ты встаешь, / Зеленым взрывом тополя разбужен» (С.М. Гандалевский «А вот и снег. Есть русские слова...». 1978); «Наотмашь бьет по векам ветер меткий. / Рассвет ушел в сугробы с головой. / Со скрежетом обледенелой веткой / Размахивает тополь угловой / Как неуютно летчику на высях! / Скитайся и туманы разрывай! (И.В. Елагин «Наотмашь бьет по векам ветер меткий...». 1939-1953).

Возвращаясь к идеальному пейзажу, следует заметить, что его характеристика будет неполной без указания на еще один его важнейший элемент - «отражение предмета в воде» (самоудвоение), через который «природа согласуется сама с собой, обретает полную цельность, завершенность, самодостаточность» [11, с. 133]. Приведем иллюстративные фрагменты, репрезентирующие «отражение предмета в воде»: Бblл дождь похож на сотни ярких стрел, / В листве играло солнце так задорно, / И тополь зачарованно смотрел / На гладь реки, спокойной и просторной (И.Г. Эренбург «Быть может...». 1948), Над речкой тополи привстали / Глядеться в глубину (С.М. Городецкий «Вечерний свет в избе на бревнах ...». 1912).

При сопоставлении всех приведенных фрагментов произведений можно выделить устойчивые поэтические формулы, посредством которых описывается тополь как элемент идеального пейзажа. Необходимо уточнить, что поэтическая формула рассматривается на ментальном уровне как архетипический образ-схема, концептуальная метафорическая модель, на речевом уровне как номинативная единица поэтической речи, как конкретный языковой вариант семантического инвариантаархетипа [5]. Например, «ветви - кров (свод, шатер), дающий тень и прохладу», «гладь воды - зеркало (сталь, серебро)», «спящая гладь воды», «деревья, которые наклоняются и смотрят в воду, как зачарованные» и т.п. Данные метафоры выполняют прежде всего художественную функцию, т.е. образно описывают внешние денотативные признаки тополя и элементов пейзажа: форму, неподвижность, гладкую и блестящую поверхность воды, притягивающую глубину воды, производимые действия и др. С помощью метафор создается целостный гармоничный образ: природа отражается в воде как красавица в зеркале, отсюда гармония во внутреннем мире природы.

Однако в поэтических формулах, актуализирующих образ тополя как элемента «троемирия», помимо наглядно-чувственных признаков, реализуются различные символические значения, связанные с мифопоэтическим образом «мирового дерева». Этот образ является первой попыткой древних людей создать картину гармонического мира, упорядоченного хаоса. Мировое дерево - мировая ось, связывающая подземный, 
земной и небесный миры, а также мир живых и мир мертвых, настоящее и прошлое, при этом символизируя память, вечность, бессмертие [4; 6].

Символическое значение бессмертия и вечности в поэтическом комплексе «троемирия» может реализовываться по принципу психологического параллелизма: погружаясь в созерцание гармонии природы лирический герой часто освобождается от мелкого и случайного, мнимо насущного, от гнетущих воспоминаний, начинает ощущать полноту жизни, видеть путь к обновлению: Был дождь похож на сотни ярких стрел, / В листве играло солнще так задорно, / И тополь зачарованно смотрел / На гладь реки, спокойной и просторной. / Пройдя так много тропок и дорог, / В весну я лишь теперь вглядеться мог. / Я ей сказал: «Ты, к счастью запоздала, / И вот могу я на тебя взглянуть!» / Потом, предавшись новой, небывалой / Мечте, добавил тихо: «Снова в путь! / И юность нагоню когда-нибудь» (И.Г. Эренбург «Быть может...». 1948).

Положительное душевное состояние лирического героя в поэзии устойчиво оказываются связаны с «четкой организацией пространства, жесткостью и ясностью граней, контрастностью, многоцветностью, яркостью, блеском, энергичным движением, ритмизованностью и гармонизированностью» [9, с. 598].

Тополь как элемент идиллемы может выступать в символическом значении дерева как знака памяти о прошлом, о родных покинутых местах: Камень лежит у жасмина. / Под этим камнем клад. / Отеи стоит на дорожке. / Белый-бельй день. / В ивету серебристый тополь, / Центифолия, а за ней - Вьющчеся розы, / Молочная трава. / Никогда я не был / Счастливей, чем тогда. / Вернуться туда невозможно / И рассказать нельзя, / Как был переполнен блаженством / Этот райский сад (А.А. Тарковский. Белый день. 1942).

Идиллема в поэтической традиции получила также метафорическое воплощение в поэтической формуле «цветение природы - цветение души»: Тополь полон волненья, $u$ липа звучит, как лира / На яблоке и на облаке ясный / Отблеск золота вечности. / Сердие, как бутон розы, раскроется скоро /От лазурной музыки мира (И.В. Чиннов «Тополь полон волненья, и липа звучит, как лира...». 1972). В приведенном иллюстративном фрагменте данная формула совмещается $\mathrm{c}$ другой устойчивой метафорой - «природа - музыка» (липа звучит как лира, лазурная музыка мира).

Таким образом, русский поэтический пейзаж организуется по закону трехмерной пространственной организации. Образным воплощением данной закономерности является устойчивый поэтический комплекс - «небо - земля - вода», который реализуется традиционными элементами идеального пейзажа. Один из этих элементов - образ дерева. Тополь как элемент идиллемы определяется как «дерево, произрастающее у воды». Данная особенность подчеркивается многочисленными обстоятельственными детерминантами, с которыми сочетается лексема «тополь». С образом тополя как элементом «троемирия» связан ряд устойчивых поэтических формул, которые обладают семантической многоплановостью: метафорически изображают наглядно-чувственный образ тополя по различным денотативным признакам, выражают символические смыслы, как правило, связанные с универсалиями-архетипами.

$$
* * *
$$

1. Витрук, О.А. Пейзаж как текстовое явление (на материале произведений англоязычных писателей XX-начала XXI вв.): автореф. дисс. ...канд. филол. Наук / О.А. Витрук. - Ростов-на-Дону, 2011. - 24 c.

2. Жукова, Н.Д. Пейзаж в «Мертвых душах» Н.В. Гоголя: автореф. дисс. ...канд. филол. наук / Н.Д. Жукова. - Днепропетровск, 1992. - 16 с.

3. Зеленцова, С.В. Функции пейзажа в малой прозе И.А. Бунина (на мате-риале произведений $1892-$ 1916 гг.): автореф. дисс. ...канд. филол. наук / С.В. Зеленцова. Орел, 2013. - 22 с.

4. Керлот, Х.Э. Словарь символов / Х.Э. Керлот. - М.: «REFL-BOOK», 1994. 608 с. 
5. Кузьмина, Н.А. Интертекст и его роль в процессах эволюции поэтического языка: монография / Н.А. Кузьмина. - Екатеринбург: Изд-во Урал. ун-та. - Омск: Омский гос. ун-т, 1999. - 268 с.

6. Мифологический словарь / гл. ред. Е.М. Мелетинский. - М. : «Большая Рос. энциклопедия», 1982.

7. Национальный корпус русского языка [Электронный ресурс]. - Режим доступа: http://search2.ruscorpora.ru. (дата обращения: 23.09.2017)

8. Руднева, О.В. Концептуализация пейзажа в малой прозе И.А. Бунина (лингвостилистический аспект): автореф. дисс. ...канд. филол. наук / О.В. руднева. - Сургут, 2007. - 26 с.

9. Топоров, В.Н. Миф. Ритуал. Символ. Образ: исследования в области мифопоэтического: Избранное / В.Н. Топоров. - Москва, 1995. - 624 с.

10. Уиллис, О.Ю. Поэтика городского пейзажа в прозе В.В. Набокова русского периода творчества: автореф. дисс. ...канд. филол. наук / О.Ю. Уиллис. - М., 2008. - 21 с.

11. Эпштейн, М.Н. «Природа, мир, тайник вселенной...»: Система пейзажных образов в русской поэзии / М.Н. Эпштейн. - М.: «Высш. школа», 1990. - 303 с.

\section{Цаллагова И.Н. \\ К вопросу о принципах разграничения лексико-семантических и тематических групा слов}

Северо-Осетинский институт гуманитарных и сочиальных исследований им. В.И. Абаева - филиал Федерального государственного бюджетного учреждения науки Федерального научного цеентра «Владикавказский научный цеентр Российской академии наук» (Россия, Владикавказ)

doi: $10.18411 / s p c-26-10-2017-09$

idsp: 000001:spc-26-10-2017-09

За последние годы интерес к общим вопросам семантики, а также к семантическому анализу лексики значительно возрос. Это привело к появлению ряда отечественных и зарубежных работ по лингвистической семантике, в которых на основе современной научной теории были более строго и четко определены основные понятия, единицы и категории семантики, разработаны методы и приемы семантического анализа лексики.

Несмотря на то, что в современном отечественном языкознании вопросы лексической семантики достаточно хорошо изучены, относительно некоторых теоретических вопросов ЛСГ в научной литературе, посвященной данной проблематике, наблюдаются некоторые расхождения. В частности, это касается того факта, что такие термины как ЛСГ, семантическое поле, тематическая группа часто употребляются как синонимы.

В отечественном языкознании семантическими полями считаются: семантические группы слов какой-либо одной части речи, семантические соотносительные группы слов разных частей речи, лексико-грамматические (функционально-семантические) поля, связанные деривационными отношениями парадигмы синтаксических конструкций, различные типы семантико-синтаксических синтагм. Несмотря на существенные различия структурного характера, объединяет их наличие в своей основе ту или иную семантическую категорию или категориальную ситуацию $[3,126]$.

Как известно, в основе систематизации лексического материала лежит учение о ЛСГ и ТГ. Одним из первых ученых, который исследовал данную проблематику и обоснованно разграничивал ЛСГ и ТГ был Ф. П. Филин [5].

По мнению Л. М. Васильева «термином ЛСГ можно обозначать любой семантический класс слов (лексем), объединенных хотя бы одной общей лексической парадигматической семой (или хотя бы одним общим семантическим множителем). К тематическим же группам следует относить лишь такие классы слов, которые объединяются одной и той же типовой ситуацией или одной темой (ср. такие темы, как 